\title{
Prevalence of Neospora caninum and Toxoplasma gondii antibodies in dogs in the municipality of Poconé, state of Mato Grosso, Brazil
}

\section{Prevalência de anticorpos contra Neospora caninum e Toxoplasma gondii no município de Poconé, estado de Mato Grosso, Brasil}

\author{
Andréia Lima Tomé Melo ${ }^{1}$; Juliana Maria Vasconcelos Grangeiro²; Daniel Moura de Aguiar $^{2}$ \\ ${ }^{1}$ Universidade de Cuiabá, Faculdade de Medicina Veterinária, Cuiabá - MT, Brazil \\ ${ }^{2}$ Universidade Federal de Mato Grosso, Faculdade de Medicina Veterinária, Cuiabá - MT, Brazil
}

\begin{abstract}
This study evaluated the presence of Neospora caninum and Toxoplasma gondii antibodies in 320 domestic dogs living in urban and rural areas of the municipality of Poconé, located in the Pantanal wetlands of the state of Mato Grosso, Brazil. Anti-N. caninum (cut-off point 50) and anti-T. gondii (cut-off point 16) antibodies were detected by means of immunofluorescence assays (IFA), using NC-Bahia and RH strains as antigens, respectively. Anti-N. caninum antibodies were detected in 69 (21.56\%; 95\% CI: 17.27\%-26.56\%) dogs, 31 (44.93\%) of which lived in urban areas and 38 (55.07\%) in rural areas, and endpoint titers ranged from 50 to 3200. Anti-T. gondii antibodies were found in 132 (41.25\%; $95 \%$ CI: 35.84\%-46.87\%) dogs, 58 (43.94\%) from urban areas and 74 (56.06\%) from rural areas, and endpoint titers ranged from 16 to 8192 . A total of 33 dogs (10.3\%) (12 urban and 21 rural animals) reacted to both agents $(\mathrm{P}<0.05)$. This study showed a higher prevalence of anti-T. gondii compared to anti-N. caninum antibodies in the dogs living in the Pantanal region, suggesting that both protozoans circulate in the studied region. This information is relevant, in view of its implications for animal and public health.
\end{abstract}

Keywords: Protozoans. Seroprevalence. IFA. Canids. Pantanal.

\section{RESUMO}

Este estudo avaliou a presença de anticorpos contra N. caninum e T. gondii em 320 cães domésticos das áreas urbana e rural do município de Poconé, no estado do Mato Grosso, região pantaneira do Pantanal. A Reação de Imunofluorescência Indireta (RIFI) foi utilizada para detectar anticorpos anti-N. caninum (ponto de corte igual a 50) e anticorpos anti-T. gondii (ponto de corte igual a 16) utilizando as cepas NC-Bahia e RH como antígenos, respectivamente. Anticorpos anti-N. caninum foram detectados em 69 (21,56\%; IC 95\%: 17,27\%-26,56\%) cães, dos quais 31 (44,93\%) eram da área urbana e 38 (55,07\%) eram da área rural e os títulos variaram entre 50 a 3200. Em relação aos anticorpos contra T. gondii 132 (41,25\%; IC 95\%: $35,84 \%-46,87 \%)$ cães foram sororeagentes sendo que 58 (43,94\%) eram da área urbana e 74 (56,06\%) da área rural e os títulos variaram entre 16 a 8192. Um total de 33 (10,31\%) (12 cães urbanos e 21 cães rurais) cães reagiram para ambos os agentes testados pela RIFI $(\mathrm{P}<0,05)$. Este estudo mostrou uma maior ocorrência de anticorpos contra T. gondii em relação a N. caninum nos cães avaliados, mostrando que na região do Pantanal há circulação desses importantes protozoários. Essa informação é relevante dada sua importância para a saúde animal e pública.

Palavras-chave: Protozoários. Seroprevalence. RIFI. Canídeos. Pantanal. 
Correspondence to:

Daniel Moura de Aguiar

Universidade Federal de Mato Grosso, Faculdade de Medicina

Veterinária

Av. Fernando Corrêa, 2367

CEP: 78060-900, Boa Esperança, Cuiabá - MT, Brazil

e-mail: danmoura@ufmt.br

Received: May 27, 2019

Approved: August 29, 2019
How to cite: Melo ALT, Grangeiro JMV, Aguiar DM. Prevalence of Neospora caninum and Toxoplasma gondii antibodies in dogs in the municipality of Poconé, state of Mato Grosso, Brazil. Braz J Vet Res Anim Sci. 2019;56(3):e158367. https://doi.org/10.11606/issn.16784456.bjvras.2019.158367

\section{Introduction}

Neospora caninum and Toxoplasma gondii are important apicomplexan pathogens characterized as obligatory intracellular parasites that can infect dogs (Reid et al., 2012). The definitive hosts of the protozoan N. caninum are canids, which eliminate oocysts in their feces. Dogs, together with other warm-blooded animals, are also considered intermediate hosts (Gondim et al., 2004; King et al., 2010; McAllister et al., 1998). Neospora caninum is associated with cases of abortion in cattle and neuromuscular disease in newborn dogs (Dubey et al., 2007).

Toxoplasma gondii, on the other hand, is one of the most common coccidian parasites that can infect animals and humans, and is considered a major public health problem in several parts of the world. The life cycle of this protozoan includes felids, which are its definitive hosts, since they eliminate the oocysts through their feces. T. gondii has a wide variety of intermediate hosts, including mammals and birds (Dubey \& Jones, 2008). T. gondii infections may be congenital or postnatal. Most infections in humans are asymptomatic, but in some cases they may be severe, particularly in immunosuppressed people (Hill \& Dubey, 2016).

Information about the epidemiology of neosporosis and toxoplasmosis has been reported in several places in Brazil, proving the widespread circulation of these protozoans (Acosta et al., 2016; Brasil et al., 2018; Cerqueira-Cézar et al., 2017; Langoni et al., 2014). The presence of anti-N. caninum antibodies has also been reported in different animals, including cattle and dogs, in the state of Mato Grosso (Benetti et al., 2008; Benetti et al., 2009; Boa Sorte et al., 2015; Melo et al., 2012; Rodrigues et al., 2016). In the Pantanal wetlands, equids have been found seropositive for both
N. caninum and T. gondii (Borges et al., 2017). In addition, a serological survey of free living jaguars (Panthera onca) in this region revealed high prevalence rates of antibodies to both parasites (Onuma et al., 2014). Given that dogs can act as sentinels for these diseases (Ullmann et al., 2008) and are usually in close contact with humans, the purpose of this study was to determine the prevalence of anti- $N$ caninum and anti-T. gondii antibodies in domestic dogs in the municipality of Poconé, located in the northern region of the Pantanal in the state of Mato Grosso, Brazil.

\section{Materials and Methods}

A total of 320 dogs in the municipality of Poconé (56 $37^{\prime} 22^{\prime \prime} \mathrm{W} ; 1^{\circ} 15^{\prime} 24^{\prime \prime} \mathrm{S}$ ) were examined for rickettsial diseases between July and September 2009 (Melo et al., 2011), and for comparison, 160 of these dogs came from urban areas and 160 dogs from rural areas. Blood samples were collected by jugular venipuncture to obtain serum. Immunofluorescence assays (IFA) were performed to detect antibodies to these pathogens, using as antigens tachyzoites of the NC-Bahia strain of N. caninum (1:50 cut-off) (Aguiar et al., 2006) and RH strain of T. gondii (1:16 cut-off) (Camargo, 1964). Each IFA slide contained sera previously known to be non-reactive (negative control) and reactive (positive control).

The owners of the dogs selected for blood collection were asked to fill out a comprehensive questionnaire that included information about the animal, as described in Table 1. Associations between the serology results and the variables obtained from the questionnaire were then inferred based on the chi-square test $\left(\mathrm{x}^{2}\right)$ or Fisher's exact test, using the Epi Info 7.1 software package. Our procedures were approved by the Bioethics Committee on Animal Research of the Federal University of Mato Grosso, under protocol no. 23108.019742/09-9.

\section{Results and Discussion}

The dogs, ranging in age from 1 to 72 months, were of different breeds and appeared to be healthy. Anti-N. caninum antibodies were detected in 69 (21.56\%; 95\% CI: 17.27\%- 26.56\%) dogs, 31 (44.93\%) of them from urban and 38 (55.07\%) from rural areas. Endpoint titers were $50(n=6), 100(n=13)$, $200(n=12), 400(n=11), 800(n=11), 1600(n=9)$ and $3200(\mathrm{n}=7)$. Anti-T. gondii antibodies were detected in 132 (41.25\%; 95\% CI: 35.84\%-46.87\%) dogs, 58 (43.94\%) from urban and $74(56.06 \%)$ from rural areas. Endpoint titers were $16(\mathrm{n}=5), 32(\mathrm{n}=16), 64(\mathrm{n}=15), 128(\mathrm{n}=30)$, $256(n=29), 512(n=17), 1024(n=13), 2048(n=2), 4096(n=4)$ and $8192(\mathrm{n}=1)$. A total of 33 dogs (10.3\%) (12 urban and 21 rural dogs) reacted to both agents tested by IFA. 
Table 1 - Analysis of variables and IFA results for anti-Neospora caninum and anti-Toxoplasma gondii antibodies from dogs in the municipality of Poconé, Mato Grosso, Brazil - 2009

\begin{tabular}{|c|c|c|c|c|c|}
\hline \multirow{3}{*}{ Analyzed variables } & \multicolumn{5}{|c|}{ No. of dogs } \\
\hline & \multirow{2}{*}{ Analyzed } & \multicolumn{2}{|c|}{ Seropositive for $N$. caninum } & \multicolumn{2}{|c|}{ Seropositive for $T$. gondii } \\
\hline & & Number (\%) & $P$-value & Number (\%) & $P$-value \\
\hline \multicolumn{6}{|l|}{ Living habitat } \\
\hline Urban & 160 & 31 (44.93) & 0.41 & $58(43.94)$ & 0.08 \\
\hline Rural & 160 & $38(55.07)$ & & $74(56.06)$ & \\
\hline \multicolumn{6}{|l|}{ Sex } \\
\hline Male & 180 & $41(59.42)$ & 0.64 & 79 (59.85) & 0.33 \\
\hline Female & 140 & $28(40.58)$ & & $53(40.15)$ & \\
\hline \multicolumn{6}{|l|}{ Access to the street } \\
\hline Yes & 127 & $30(43.48)$ & 0.55 & $54(40.91)$ & 0.79 \\
\hline No & 193 & $39(56.52)$ & & 78 (59.09) & \\
\hline \multicolumn{6}{|l|}{ Access to rural areas } \\
\hline Yes & 196 & $46(66.67)$ & 0.36 & $94(71.21)$ & 0.00 \\
\hline No & 124 & $23(33.33)$ & & 38 (28.79) & \\
\hline \multicolumn{6}{|l|}{ Type of diet* } \\
\hline Home-cooked food & 174 & $42(60.87)$ & 0.30 & $81(61.83)$ & 0.04 \\
\hline Mixed $^{* *}$ & 144 & $27(39.13)$ & & $50(38.17)$ & \\
\hline \multicolumn{6}{|l|}{ Contact with dogs } \\
\hline Yes & 260 & $57(82.61)$ & 0.87 & $103(78.03)$ & 0.27 \\
\hline No & 60 & $12(17.39)$ & & $29(21.97)$ & \\
\hline \multicolumn{6}{|l|}{ Contact with felids } \\
\hline Yes & 145 & $37(53.62)$ & 0.15 & $62(46.97)$ & 0.70 \\
\hline No & 175 & $32(46.38)$ & & $70(53.03)$ & \\
\hline \multicolumn{6}{|c|}{ Contact with animal food products } \\
\hline Yes & 185 & $44(63.77)$ & 0.32 & $87(65.91)$ & 0.01 \\
\hline No & 135 & $25(36.23)$ & & 45 (34.09) & \\
\hline \multicolumn{6}{|l|}{ Contact with wild animals } \\
\hline Yes & 188 & $45(65.22)$ & 0.27 & 89 (67.42) & 0.01 \\
\hline No & 132 & $24(34.78)$ & & $43(32.58)$ & \\
\hline \multicolumn{6}{|l|}{ Hunting behavior } \\
\hline Yes & 100 & $30(43.48)$ & 0.01 & $46(34.85)$ & 0.29 \\
\hline No & 220 & 39 (56.52) & & $86(65.15)$ & \\
\hline \multicolumn{6}{|l|}{ Age } \\
\hline 0-12 months & 99 & $14(20.29)$ & 0.04 & $21(15.91)$ & 0.00 \\
\hline $12-24$ months & 67 & 20 (28.99) & 0.09 & 25 (18.94) & 0.55 \\
\hline $24-48$ months & 72 & $14(20.29)$ & 0.73 & 38 (28.79) & 0.03 \\
\hline$>48$ months & 78 & $21(30.43)$ & 0.24 & 46 (34.85) & 0.00 \\
\hline Indeterminate & 4 & $0(0.0)$ & 0.58 & $2(1.52)$ & 1.00 \\
\hline
\end{tabular}

*The diet of 2 dogs could not be determined; **Mixed: a combination of home-cooked and commercial dog food.

The prevalence of anti-N. caninum antibodies was associated with age and hunting behavior $(\mathrm{P}<0.05)$. On the other hand, anti-T. gondii antibody prevalence was associated with age, access to rural areas, type of diet and contact with farm and wild animals $(\mathrm{P}<0.05$; Table 1$)$.

Our findings indicated that urban and rural dogs in the northern region of Pantanal were equally exposed to $N$. caninum and T. gondii. Although no association was found between the variables of urban/rural environment and the prevalence of the two agents, associations were found between several other variables. The association between young aged animals and seropositivity for N. caninum in dogs appears to suggest possible transplacental transmission
(Cavalcante et al., 2012), which is also supported by the non-hunting behavior of many of these dogs. In contrast, an association was found between older dogs and the prevalence of $T$. gondii, indicating that the dogs in this region were exposed to this coccidian parasite for longer periods of time during their life, which suggests that the main route of infection in dogs is horizontal transmission (Cañón-Franco et al., 2003; Cano-Terriza et al., 2016).

The findings about $T$. gondii are supported by other associations, including access to rural areas, home cooked diet, contact with animal food products and wild animals. All these variables may be related to contaminated environments or food to which these dogs may have been exposed during 
their life. The association between home-cooked diets and the seropositivity to the protozoan T. gondii is relevant, given that infections by this agent may also be acquired by ingesting tissue-inhabiting stages of the parasite and that any animal tissues, especially undercooked meat containing cysts with bradyzoites, may be a source of infection for dogs (Hill et al., 2005). Borges et al. (2017), who evaluated equids in this region, found a large number of seropositive animals. In this context, the possible contribution of domestic or wild felids should be considered, since the presence of cats in urban areas and on farms is common; in fact, 50\% of the dogs in our study have contact with cats. Moreover, the presence of wild felids in this region is frequent, and high titers of anti- $T$. gondii antibodies have been detected in local free-living jaguars (Onuma et al., 2014).

\section{Conclusions}

The prevalence of anti-T. gondii and anti-N. caninum antibodies among these dogs indicates that these coccidia are circulating in the Pantanal. This information is relevant,

\section{References}

Acosta ICL, Centoducatte LDA, Soares HS, Marcili A, Gondim MFN, Rossi JL Jr, Gennari SM. Occurrence of Neospora caninum and Toxoplasma gondii antibodies in dogs from rural properties surrounding a biological reserve, Espírito Santo, Brasil. Rev Bras Parasitol Vet. 2016;25(4):536-9. http:// dx.doi.org/10.1590/s1984-29612016075. PMid:27925068.

Aguiar DM, Cavalcante GT, Rodrigues AAR, Labruna MB, Camargo LMA, Camargo EP, Gennari SM. Prevalence of anti-Neospora caninum antibodies in cattle and dogs from Western Amazon, Brazil, in association with some possible risk factors. Vet Parasitol. 2006;142(1-2):71-7. http://dx.doi. org/10.1016/j.vetpar.2006.06.014. PMid:16857319.

Benetti AH, Schein FB, Santos TR, Toniollo GH, Costa AJ, Mineo JR, Lobato J, Silva DAO, Gennari SM. Pesquisa de anticorpos anti-Neospora caninum em bovinos leiteiros, cães e trabalhadores rurais da região Sudoeste do Estado de Mato Grosso. Rev Bras Parasitol Vet. 2009;18(supl. 1):29-33. http://dx.doi.org/10.4322/rbpv.018e1005. PMid:20040187.

Benetti AH, Toniollo GH, Santos TR, Gennari SM, Costa AJ, Dias RA. Ocorrência de anticorpos anti-Neospora caninum em cães no município de Cuiabá, Mato Grosso. Cienc Anim Bras. 2008;9(1):177-80.

Boa Sorte EC, Almeida ABPF, Cruz FACS, Gasparetto ND, Godoy I, Dutra V, Amendoeira MRR, Sousa VRF. given the importance of these parasites to public and animal health.

\section{Conflict of Interest}

The authors declare that there is no conflict of interest.

\section{Ethics Statement}

This study was evaluated by the Animal Research Ethics Committee of the Federal University of Mato Grosso and was approved under Protocol no 23108.019742/09-9.

\section{Acknowledgements}

The authors gratefully acknowledge the National Council for Scientific and Technological Development (CNPq) for the financial support (process no. 472178/2008-3) and for awarding a research productivity (303677/2018-0) grant to D.M. Aguiar. The first author thanks God for his life and for his work for veterinary medicine.

Serological and molecular detection of Toxoplasma gondii in dogs of urban and rural areas of Cuiabá, Mato Grosso. Semina: Ciênc Agrár. 2015;36(6):3705-12. http://dx.doi. org/10.5433/1679-0359.2015v36n6p3705.

Borges AMCM, Yeargan MR, Silva LG, Taques ÍIGG, Howe D, Aguiar DM. Antibodies against Sarcocystis neurona, Neospora spp., and Toxoplasma gondii in horses and mules from the Northern Pantanal Wetland of Brazil. J Equine Vet Sci. 2017;56:19-25. http://dx.doi.org/10.1016/j.jevs.2017.04.007.

Brasil AWL, Parentoni RN, Silva JGD, Santos CSAB, Mota RA, Azevedo SS. Risk factors and anti-Toxoplasma gondii and Neospora caninum antibody occurrence in dogs in João Pessoa, Paraíba state, Northeastern Brazil. Rev Bras Parasitol Vet. 2018;27(2):242-7. http://dx.doi.org/10.1590/ s1984-29612018006. PMid:29846448.

Camargo ME. Improved technique of indirect immunofluorescence for serological diagnosis of toxoplasmosis. Rev Inst Med Trop São Paulo. 1964;6:117-8. PMid:14177810.

Cañón-Franco WA, Bergamaschi DP, Labruna MB, Camargo LMA, Souza SLP, Silva JCR, Pinter A, Dubey JP, Gennari SM. Prevalence of antibodies to anti-Neospora caninum in dogs from Amazon, Brazil. Vet Parasitol. 2003;115(1):714. http://dx.doi.org/10.1016/S0304-4017(03)00131-6. PMid:12860070. 
Cano-Terriza D, Puig-Ribas M, Jiménez-Ruiz S, Cabezón Ó, Almería S, Galán-Relaño Á, Dubey JP, García-Bocanegra I. Risk factors of Toxoplasma gondii infection in hunting, pet and watchdogs from southern Spain and northern Africa. Parasitol Int. 2016;65(5 Pt A):363-6. http://dx.doi. org/10.1016/j.parint.2016.05.001. PMid:27155133.

Cavalcante GT, Soares RM, Nishi SM, Hagen SCF, Vannucchi CI, Maiorka PC, Paixão AS, Gennari SM. Experimental infection with Neospora caninum in pregnant bitches. Rev Bras Parasitol Vet. 2012;21(3):232-6. http://dx.doi. org/10.1590/S1984-29612012000300010.

Cerqueira-Cézar CK, Calero-Bernal R, Dubey JP, Gennari SM. All about neosporosis in Brazil. Rev Bras Parasitol Vet. 2017;26(3):253-79. http://dx.doi.org/10.1590/s198429612017045. PMid:28876360.

Dubey JP, Jones JL. Toxoplasma gondii infection in humans and animals in the United States. Int J Parasitol. 2008;38(11):1257-78. http://dx.doi.org/10.1016/j. ijpara.2008.03.007. PMid:18508057.

Dubey JP, Schares G, Ortega-Mora LM. Epidemiology and control of Neosporosis and Neospora caninum. Clin Microbiol Rev. 2007;20(2):323-67. http://dx.doi.org/10.1128/ CMR.00031-06. PMid:17428888.

Gondim LFP, Mcallister MM, Pitt WC, Zemlicka DE. Coyotes (Canis latrans) are definitive hosts of Neospora caninum. Int J Parasitol. 2004;34(2):159-61. http://dx.doi. org/10.1016/j.ijpara.2004.01.001. PMid:15037103.

Hill DE, Chirukandoth S, Dubey JP. Biology and epidemiology of Toxoplasma gondii in man and animals. Anim Health Res Rev. 2005;6(1):41-61. http://dx.doi.org/10.1079/ AHR2005100. PMid:16164008.

Hill DE, Dubey JP. Toxoplasma gondii as a parasite in food: analysis and control. Microbiol Spectr. 2016;4(4):1-17. http://dx.doi.org/10.1128/microbiolspec.PFS-0011-2015. PMid:27726776.

King JS, Slapeta J, Jenkins DJ, Al-Qassab SE, Ellis JT, Windsor PA. Australian dingoes are definitive hosts of Neospora caninum. Int J Parasitol. 2010;40(8):945-50. http://dx.doi. org/10.1016/j.ijpara.2010.01.008. PMid:20149793.

Langoni H, Fornazari F, Silva RC, Monti ET, Villa FB. Prevalence of antibodies against Toxoplasma gondii and Neospora caninum in dogs. Braz J Microbiol. 2014;44(4):132730. http://dx.doi.org/10.1590/S1517-83822013000400043. PMid:24688530.
McAllister MM, Dubey JP, Lindsay DS, Jolley WR, Wills RA, McGuire AM. Dogs are definitive hosts of Neospora caninum. Int J Parasitol. 1998;28(9):1473-8. http://dx.doi. org/10.1016/S0020-7519(98)00138-6. PMid:9770635.

Melo ALT, Martins TF, Horta MC, Moraes-Filho J, Pacheco RC, Labruna MB, Aguiar DM. Seroprevalence and risk factors to Ehrlichia spp. and Rickettsia spp. in dogs from the Pantanal region of Mato Grosso State, Brazil. Ticks Tick Borne Dis. 2011;2(4):213-8. http://dx.doi.org/10.1016/j. ttbdis.2011.09.007. PMid:22108015.

Melo ALT, Silva GCP, Aguiar DM. Soroprevalência de anticorpos anti-Neospora caninum em cães da cidade de Cuiabá, Estado de Mato Grosso. Semina: Ciênc Agrár. 2012;33(4):1507-14. http://dx.doi.org/10.5433/16790359.2012v33n4p1507.

Onuma SSM, Melo ALT, Kantek DLZ, Crawshaw-Junior PG, Morato RG, May-Júnior JA, Pacheco TA, Aguiar DM. Exposure of free-living jaguars to Toxoplasma gondii, Neospora caninum and Sarcocystis neurona in the Brazilian Pantanal. Rev Bras Parasitol Vet. 2014;23(4):547-53. http:// dx.doi.org/10.1590/s1984-29612014077. PMid:25517539.

Reid AJ, Vermont SJ, Cotton JA, Harris D, Hill-Cawthorne GA, Könen-Waisman S, Latham SM, Mourier T, Norton R, Quail MA, Sanders M, Shanmugam D, Sohal A, Wasmuth JD, Brunk B, Grigg ME, Howard JC, Parkinson J, Roos DS, Trees AJ, Berriman M, Pain A, Wastling JM. Comparative genomics of the apicomplexan parasites Toxoplasma gondii and Neospora caninum: Coccidia differing in host range and transmission strategy. PLOS Pathogens. 2012;8(3), e1002567. https://doi.org/10.1371/journal.ppat.1002567.

Rodrigues JY, Almeida ABPF, Boa Sorte EC, Gasparetto ND, Cruz FACS, Sousa VRF. Seroprevalence of Toxoplasma gondii in dogs of riverside communities of Mato Grosso Pantanal, Brazil. Rev Bras Parasitol Vet. 2016;25(4):531-5. http:// dx.doi.org/10.1590/s1984-29612016067. PMid:27925062.

Ullmann LS, Guimarães FF, Fornazari F, Tomé RO, Camossi LG, Greca H, Silva RC, Menozzi BD, Langoni H. Ações de vigilância continuada, papel do cão como animal sentinela para toxoplasmose. Rev Bras Parasitol Vet. 2008;17(supl. 1):345-7. PMid:20059876.

Financial Support : CAPES (Federal Agency for the Support and Improvement of Higher Education) and CNPq (National Council for Scientific and Technological Development).

Authors Contributions: All authors contributed to the realization of this article. 